\title{
p-ISSN 2302-0970 \\ e-ISSN 2723-0201 \\ PERAN KEPEMIMPINAN LURAH DALAM MENINGKATKAN PARTISIPASI MASYARAKAT DI KELURAHAN LALEBATA KECAMATAN PANCA RIJANG KABUPATEN SIDENRENG RAPPANG
}

\author{
Surya S. \\ Fakultas IImu Sosial dan IImu Politik Universitas Muhammadiyah Sidenreng Rappang \\ suryasulaiman768@gmail.com
}

\begin{abstract}
Abstrak
Tujuan penelitian ini yaitu untuk mengetahui peran Kepemimpinan Lurah dalam meningkatkan Partisipasi Masyarakat di Kelurahan Lalebata Kecamatan Panca Rijang Kabupaten Sidenreng Rappang. Jenis dan tipe penelitian ini menggunakan Deskriptif Kuantitatif, populasi dalam penelitian ini adalah seluruh masyarakat Kelurahan Lalebata sebanyak 6013, sampel penelitian ini sebanyak 98 orang, Tehnik pengumpulan data yang dilakukan dalam penelitian ini adalah dengan menggunakan tehnik (1) Observasi, (2) Wawancara, (3) Kuisioner, (4) Studi Kepustakaan. Hasil Penelitian ini menunjukkan bahwa peran Kepemimpinan Lurah dalam meningkatkan Partisipasi Masyarakat di Kelurahan Lalebata lebih dominan yaitu kepemimpinan Demokratif dengan hasil ratarata persentase $75,6 \%$ atau dikategorikan Berpengaruh, Faktor-faktor yang mmpengaruhi Kepemimpinan Lurah yaitu sebesar $60 \%$ atau dikategorikan Cukup Berpengaruh, dan indikator partisipasi masyarakat dalam pengambilan Keputusan dengan hasil rata-rata persentase sebesar $47 \%$ atau dikategorikan Cukup Berpengaruh.
\end{abstract}

Kata Kunci : Peran dan Partisipasi Masyarakat

\begin{abstract}
The purpose of this study is to determine the role of village head leadership in increasing community participation in Lalebata Village, Panca Rijang District, Sidenreng Rappang Regency. The type and type of this research uses descriptive quantitative, the population in this study is all of the people of Lalebata Village as many as 6013, the sample of this study was 98 people, the data collection techniques used in this study were to use (1) observation, (2) interview, (3) Questionnaires, (4) Literature Study. The results of this study indicate that the role of the village head leadership in increasing community participation in Lalebata village is more dominant, namely democratic leadership with an average percentage of $75.6 \%$ or categorized as Influential, the factors that influence the village head leadership are $60 \%$ or categorized as sufficiently influential, and indicators of community participation in decision making with an average percentage of $47 \%$ or categorized as Moderately Influential.
\end{abstract}

Keywords: Community Role and Participation 


\section{A. PENDAHULUAN}

Pelaksanaan Otonomi Daerah yang telah digulirkan oleh pemerintah sejak tahun 2011 membawa perubahan dalam pelaksanaan pemerintahan didaerah. Salah satu perubahan itu adalah pemberian wewenang yang luas dalam peyelenggaraan beberapa bidang pemerintahan. Dengan bertambah luasnya kewenangan ini, maka aparat pemerintahan di daerah diharapkan dapat mengelola dan menyelenggarakan pelayanan dengan lebih baik dari sebelumnya sesuai dengan kebutuhan dan harapan masyarakat. Kelurahan merupakan dasar dari satuan pemerintahan yang terkecil dari suatu komunitas pemerintahan negara. Sehingga boleh dikatakan bahwa keberhasilan dalam melakukan pembangunan juga tergantung dari sejauh mana partisipasi masyarakat setempat beserta aparatur pemerintahan kelurahan dalam perencanaan pembangunan tersebut, masyarakat harus ikut berpartisipasi dan diberi kepercayaan dan kewenangan yang cukup dalam mengurusi rumah tangga kelurahannya, sehingga bisa mandiri selain sebagai pelaksanadan perencana program pembangunan, maka para aparatur pemerintah kelurahan juga berperan sebagai pelayan masyarakat dalam dan sesuai dengan potensi dan sumber daya yang dimiliki daerah tersebut.

Kelurahan dipimpin oleh seorang Lurah yang berstatus sebagai Pegawai Negeri Sipil sesuai Peraturan Pemerintah No.73 tahun 2005. Disebutkan Lurah haruslah memiliki syarat-syarat berupa kemampuan teknis dibidang administrasi pemerintahan dan memahami kondisi sosial budaya masyarakat setempat. Peraturan Pemerintah Nomor. 11 Tahun 2017 tentang Badan Kepewaian Negara, bahwa 'Pegawai Aparatur Sipil Negara yang selanjutnya disebut Pegawai ASN adalah pegawai Negeri Sipil dan Pegawai Pemerintah dengan perjanjian kerja yang diangkat oleh pejabat Pembina kepegawai dan serahi tugas dalam suatu jabatan pemerintah atau disertai tugas Negera lainnya dan digaji berdasarkan peraturan Perundang-undang'. Pelaksana dan perencana program pembangunan, maka para aparatur pemerintah kelurahan juga berperan sebagai pelayan masyarakat dalam urusan-urusan administrasi dan kependudukan yang menjadi wewenang dari pihak kelurahan. Peraturan Pemerintah Republik IndonesiaNo. 73 Tahun 2005
p-ISSN 2302-0970

e-ISSN 2723-0201

tentang Pemerintah Kelurahan yang merupakan dasar dalam menuju masyarakat yang berkembang yaitu kelurahan tidak lagi menjadi level adminitrasi, tidak lagi menjadi bawahan daerah tetapi menjadi masyarakat yang mandiri. Sehingga setiap masyarakat yang berada pada lingkungan kelurahan berhak berbicara dan mengeluarkan pendapat sesuai dengan kepentingan sendiri. Disni harus dipahami bahwa kelurahan merupakan suatu kesatuan hukum yang memiliki hak dan kekuasaan dalam mengatur dan melayani semua kebutuhan dan kepentingan masyarakatnya menuju kesejahtraaan.

Pemerintah kelurahan juga harus cepat dan tanggap dalam memperhatikan segala sesuatu yang menjadi kebutuhan warga masyarakatnya.diharapkan dengan terciptanya pemerintahan kelurahan yang tangguh dan mandiri yang dapat memenuhi kebutuhan-kebutuhan masyarakat dalam rangka untuk meningkatkan kesejahteraan nasyarakat, dan mewujudkn program pembangunan yang terencana secara efektif dan efisien yang pada akhirnya diharapkan dapat mewujudkan cita-cita masyarakat yang adil dan sejahtera. Kepemimpinan Kepala Kelurahan merupakan faktor penting untuk menentukan kemajuan desa yang menjadi tanggung jawab, tetapi seorang Kepala kelurahan juga tidak mungkin melaksanakan tugas dan tanggung jawabnya untuk menjadikan kelurahan semakin maju tanpa adanya dukungan dan partisipasi dari masyarakat, untuk itu kepemimpinan dan juga partisipasi dari masyarakat harus berjalan secara seiring dan sejalan agar tercipta suasana yang kondusif dan harmonis sehingga tujuan dan cita-cita untuk menjadikan kelurahan yang diimpikannya semakin baik dan bisa terwujud.

Seperti yang terlihat di Kelurahan Lalebata penyelenggaraan pemerintahan bertugas dan berkewajiban terhadap seluruh kegiatan pemerintahan adalah Kepala Kelurahan, adapun tugas dan kewajibannya Kepala Kelurahan adalah salah satunya memimpin penyelenggaraan pemerintahan kelurahan, oleh karena itu Kepala Kelurahan dalam menyelenggarakan pemerintahan tidak mungkin dilakukan sendiri, Kepala Kelurahan juga perlu partisipasi dari semua lapisan masyarakat masyarakat untuk ikut mensukseskan program pembangunan yang ada. Peran Kepala Kelurahan sangat diperlukan dalam hal peningkatan kesadaran 
masyarakat untuk ikut berpartisipasi dalam program-program kelurahan. Dan upaya Kepala kelurahan dalam meningkatkan partisipasi masyarakat salah satunya ditujukan dengan cara pendekatan terhadap warga, berdasarkan observasi yang dilakukan terkait Peran Kepemimpinan Lurah, yaitu masih kurangnya partisipasi masyarakat dalam melaksanakan kegiatan kelurahan hal ini terlihat dengan kurangnya masyarakat yang datang ketika ingin diadakan rapat misalnya dalam acaa Musrenbang, dan kurangnya kerjasama dengan pihak kelurahan pada saat pembersihan diarea masingmasing, hal ini terjadi karena kepala Kelurahan kurang bersosialisasi dan kurang membangun kedekatan kepada masyarakat sehingga mempengaruhi kegiatan gotong royong yang ada di kelurahan Lalebata. Berdasarkan dengan adanya latar belakang masalah diatas maka penulis tertarik melakukan penelitian dengan judul " Peran Kepemimpinan Lurah dalam Meningkatkan Partisipasi Masyarakat di Kelurahan Lalebata Kecamatan Panca Rijang Kabupaten Sidenreng Rappang dengan tujuan untuk mengetahui Peran Kepemimpinan Lurah dalam Meningkatkan Partisipasi Masyarakat di Kelurahan Lalebata Kecamatan Panca Rijang Kabupaten Sidenreng Rappang dan danuntuk mengetahui faktor-faktor yang mempengaruhi Peran Kepemimpinan Lurah dalam Meningkatkan Partisipasi Masyarakat di Kelurahan Lalebata Kecamatan Panca Rijang Kabupaten Sidenreng Rappang.

Peranan adalah merupakan aspek dinamis kedudukan (status), apabila sesorang melaksanakan hak dan kwajibannya sesuai dengan kedudukannya, maka dia menjalankan peranan (Soerjono, 2007). Menurut (Abdulsyani, 2012) peranan adalah suatu perbuatan sesorang dengan cara tertentu dalam usaha menjalankan hak dan kewajibannya sesuai dengan status yang dimilikinya, dan seseorang dapat dikatakan berperan jika ia telah melaksanakan hak dan kewajibannya sesuai dengan status sosialnya dalam masyarakat. Lebih lanjut (Sutarto, 2009) mengemukakan peranan ini terdiri dari tiga komponem yaitu (1) Kepercayaan Seseorang tentang apa yang dilakukan dengan suatu situasi tertentu, (2) Harapan peran yaitu harapan orang terhadap seseorang yang menduduki posisi tertentu mengenai bagaimana dia seharusnya bertindak (3) Pelaksanaan peran yaitu perilaku sesungguhnya dari seseorang yang berada pada suatu posisi tertentu, apabila ketiga komponem tersebut diatas berlangsung serasi, maka interaksi sosial akan terjalin kesinambungan dan kelancarannya.

Menurut Indriyo Gitosudarmodan I Nyoman Sudita (Sunyoto, 2012) Kepemimpinan adalah sebagai suatu proses mempengaruhi aktivitas dari individu atau kelompok untuk mencapai tujuan dalam situasi tertentu. Kepemimpinan adalah setiap upaya sesorang yang mencoba untuk mempengaruhi tingkah laku atau kelompok, upaya untuk mempengaruhi tingkah laku ini bertujuan mencapai tujuan perorangan, tujuan teman, atau bersama-sama dengan tujuan organisasi yang mungkin sama atau berbeda Hersey dan blanchart (Sunyoto, 2012). Nawawi (Harbani, 2014). Kepemimpinan adalah kemampuan atau kecerdasan mendorong sejumlah orang (dua orang atau lebih), agar bekerja sama dalam melaksanakan kegiatan-kegiatan yang terarah pada tujuan bersama. (Kartini, 2016). Indikator Kepemimpinan ada lima yaitu:

1. Kepemimpinan Otokrasi yaitu dalam pengambilan keputusan dipusatkan pada pimpinan, dalam hal ini pemimpin bebas untuk mennetukan kebijakan dan menyusun, mendefenisikan atau medifikasi tugas-tugas sesuai keinginannya.

2. Kepemimpinan Demogratif yaitu pemimpin yang populer pada era manajemen neo klasik, partisipati agar terwujud kerjasama dalam rangka pencapaian tujuan organisasi dengan membudayakan bawahan dengan ikut serta dalam pengambilan keputusan.

3. Kepemimpinan Karismatik yaitu pemimpin yang bertipe karismatik sehingga ia mempunyai pengikut tanpa dimobilisasi.

4. Kepemimpinan Lissez Faire yaitu pemimpin yang memberikan kebebasan kepada bawahannya untuk bertindak tanpa diperintahkan.

5. Kepemimpinan Paternalistik yaitu seorang pemimpin memiliki hubungan kekeluargaan dan ikatan yang kuat dengan masyarakat.

Corvey (Veithzal, 2012) membagi faktorfaktor yang mempengaruhi Kepemimpinan ada tiga yaitu :

1. Pencarian Alur (Pahfinding) yaitu seorang pemimpin berperan untuk menentukan visi dan misi yang pasti, agar masyarkat bisa 
dengan sendirinya berpartisipasi dalam segala kegiatan.

2. Penyelaras (Aligning) yaitu seorang pemimpin berperan untuk memastikan bahwa struktur, system dan operasional organisasi memberikan dukungan pada pencapaian visi dan misi Kelurahan.

3. Pemberdaya (Empowering) yaitu seorang pemimpin berperan untuk menggerakkan semangat dalam diri masyarakat yang kreatif untuk menggerakkan semangat dalam diri masyarakat yang kreatif untuk mengerjakan apapun.

Partisipasi adalah keterlibatan mental/pikiran atau moral/perasaan di dalam situasi kelompok yang mendorongnya untuk memberikan sumbangan kepada kelompok dalam usaha mencapai tujuan serta turut bertanggung jawab terhadap usaha yang bersangkutan. Menurut Siti Irene, 2011:50 partisipasi adalah merupakan keterlibatan mental dan emosi dari seorang di dalam situasi kelompok yang mendorong mereka untuk menyokong kepada pencapaian tujuan pada tujuan kelompok tersebut dan ikut bertanggung jawab terhadap kelompoknya. Partisipasi adalah keikutsertaan dan keterlibatan masyarakat secara aktif dalm proses perencanaan pembangunan (Peraturan Menteri Dalam Negeri Nomor 5 tahun 2007). Menurut (Totok, 2015) bentuk Partisipasi masyarakat ada empat yaitu:

1. Partisipasi dalam pengambilan keputusan yaitu keikutsertaan masyarakat kelurahan dalam perencanaan dan pengambilan keputusan untuk program-program pembangunan.

2. Partisipasi dalam pelaksanaan kegiatan yaitu Keikutsertaan masyarakat dalam pelaksanaan kegiatan pembangunan.

3. Partisipasi dalam pemantauan dan evaluasi pembangunan yaitu keikutsertaan masyarakat dengan tujuan untuk memperoleh umpan balik tentang masalahmasalah dan kendala yang muncul pelaksanaan pembangunan.

4. Partisipasi dalam pemanfaatan hasil pembangunan yaitu Keikutsertaan masyarakat dalam memnfaatkan hasil pembangunan guna memperbaiki mutu hidup masyarakat banyak.

Menurut (E, 2004) partisipasi masyarakat dalam proses pembangunan dapat dipilih meliputi : (1) partisipasi dalam/melalui kontak dengan pihak lain sebagai awal perubahan sosial, (2) partisipasi
e-ISSN 2723-0201

dalam memperhatikan/menyerap dan memberi tanggapan terhadap informasi baik dalam arti menerima, menerima dengan syarat, maupun dalam arti menolaknya, (3) partisipasi dalam perencanaan termasuk pengambilan keputusan, (4) partisipasi dalam pelaksanaan operasional, (5) partisipasi dalam menerima, memeliharadan mengembangkan hasil pembangunan, yaitu ketertiban masyarakat dalam menilai tingkat pelaksanaan pembangunan.

\section{B. METODE PENELITIAN}

Metode penelitian yang digunakan yaitu mengguganakan metode Kuantitatif yaitu suatu model penelitian yang bersifat induktif, objektif dan ilmiah dengan data yang diperoleh berupa angka atau pernyataan dan juga menganalisis meggunakan analisis statistik. Populasi yang digunakan dalam penelitian ini adalah seluruh masyarakat di Kelurahan Lalebata kecamatan Panca Rijang Kabupaten Sidenreng Rappang yang berjumlah 6013 jiwa. Teknik penentuan sampel yang digunakan adalah rumus Slovin dengan tingkat kesalahan 10\% maka dari itu penelitian ini dengan jumlah 98 orang. Teknik pengumpulan data yang digunakan adalah melakukan Observasi, Kuisioner, dan studi pustaka sedangkan teknik analisis data yang digunakan adalah teknik analisis data kuantitatif dengan bantuan program SPSS versi 16, hasil analisis berupa statistic deskriptif, uji kualitas (uji validitas dan uji reabilitas), dan analisis regresi linear.

\section{HASIL DAN PEMBAHASAN}

Hasil persentase dari lima item pertanyaan pada indikator di atas, maka di dapatkan hasil rata-rata persentase yaitu $67 \%$ atau kategori Berpengaruh. Berdasarkan data yang terkumpul setelah dihitung dapat ditemukan bahwa jumlah skor variabel kepemimpinan dan faktor yang mempengaruhi Kepemimpinan Lurah $=3.052$ jumlah skor ideal kedua variabel tersebut $5 \mathrm{x}$ $5 \times 98=2.450$ dengan demikian diperoleh nilai $=2.450: 3.052 \times 100=80 \%$.jadi pengaruh kepemimpinan Lurah terhadap faktor yang mempengaruhi kepemimpinan Lurah di kelurahan Lalebata Kecamatan Panca Rijang Kabupaten Sidenreng Rappang sebesar $80 \%$ atau di kategorikan Berpengaruh. Sesuai dengan hal tersebut pengambilan suatu keputusan atau kebijakan seorang pemimpin dalam hal ini adalah Lurah Lalebata, 
seharusnya memberikan kebebasan kepada masyarakatnya untuk memberikan pendapat atau masukan dan dapat dipertimbangkan dengan baik, dan mengikut sertakan dalam pengambilan Keputusan dalam segala kegiatan yanag ada di Kelurahan.

Hasil dari tiga item pertanyaan pada indikator di atas, maka didapatkan hasil ratarata persentase yaitu $74,5 \%$ atau di kategorikan Berpengaruh Berdasarkan data yang terkumpul setelah di hitung dapat di temukan bahwa jumlah skor variabel faktorfaktor yang mempengaruhi Kepemimpinan Lurah dan Partisipasi Masyarakat $=2.482$ jumlah skor ideal dari variabel tersebut $5 \times 3 \times$ $98=1.470$ dengan demikian di peroleh nilai $=$ $1.470: 2.482 \times 100=60 \%$. jadi faktor-faktor yang mempengaruhi kepemimpinan Lurah terhadap Partisipasi Masyarakat di Kelurahan Lalebata Kecamatan Panca Rijang Kabupaten Sidenreng Rappang sebesar $60 \%$ atau dikategorikan Cukup Berpengaruh. Kepemimpinan yang baik yaitu seorang pemimpin menentukan berperan untuk menentukan visi dan misi, struktur dan system organisasi yang pasti, untuk menggerakkan semangat dalam diri masyarakat yang kreatif, agar masyarakat bisa dengan sendirinya berpartisipasi dalam segala kegiatan di Kelurahan Lalebata Kecamatan Panca Rijang Kabupaten Sidenreng Rappang" (17 September 2017).

Hasil rata-rata persentase dari empat item pertanyaan pada indikator diatas, maka di dapatkan hasil rata-rata persentase, yaitu $71 \%$ atau kategori Berpengaruh. Berdasarkan data yang terkumpul setelah di hitung dapat ditemukan bahwa jumlah skor variabel Kepemimpinan Lurah dan Faktor-faktor yang mempengaruhi Kepemimpinan Lurah terhadap Partisipasi Masyarakat $=4.148$ jumlah skor ideal kedua variabel tersebut $5 \mathrm{x}$ $4 \times 98=1.960$ dengan demikian diperoleh nilai $=1.960: 4.148 \times 100=47 \%$, jadi peran Kepemimpinan Lurah terhadap Partisipasi Masyarakat di Kelurahan Lalebata Kecamatan Panca Rijang Kabupaten Sidenreng Rappang sebesar $47 \%$ atau dikategorikan Cukup Berpengaruh. Partisipasi Masyarakat yaitu keikutsertaan masyarakat dalam perencanaan, pelaksanaan dan pengambilan keputusan, baik berupa ide, tenaga maupun materi untuk program-program baik fisik maupun non fisik, dalam memamfaatkan hasil pembangunan guna memperbaiki mutu hidup masyarakat di Kelurahan Lalebata Kecamatan
Panca Rijang Kabupaten Sidenreng Rappang" (17 September 2017).

\section{KESIMPULAN}

Berdasarkan hasil pembahasan sebelumnya, maka dapat ditarik simpulan sebagai berikut:

1. Peran Kepemimpinan Lurah dalam meningkatkan Partisipasi Masyarakat di Kelurahana Lalebata Kecamatan Panca Rijang Kabupaten Sidenreng Rappang lebih dominan yaitu Kepemimpinan Demokratif dengan rata-rara persentase $75,6 \%$ atau dikategorikan Berpengaruh. melihat kurangnya kerjasama antara Kepala Kelurahan dengan masyarakat Kelurahan Lalebata Kecamatan Panca Rijang Kabupaten Sidenreng Rappang,berdasarkan hasil penelitina ini menunjukkan bahwa Faktor-faktor yang mempengaruhi Kepemimpinan Lurah terhadap Partisipasi Masyarakat yaitu sebesar $60 \%$ atau di kategorikan Cukup Berpengaruh.

2. Kurangnya tingkat Partisipasi Masyarakat di Kelurahan Lalebata Kecamatan Panca Rijang Kabupaten Sidenreng Rappang, khususnya partisipasi dalam pengambilan Keputusan, dalam penelitian ini berdasarkan tanggapan responden menunjukkan bahwa tingkat partisipasi masyarakat yaitu $47 \%$ atau dikategorikan Cukup Berpengaruh.

\section{E. REFERENSI}

Abdulsyani. (2012). Sosiologi Skematik, Teori dan Terapan. Jakarta: Bumi Aksara.

E, L. (2004). Partisipasi dalam Proses Pembangunan. Jakarta: Khanata.

Harbani, P. (2014). Kepemimpinan Birokrasi. Bandung: Alfabeta.

Kartini, K. (2016). Pemimpin dan Kepemimpinan. Jakarta: Raja Grafindo Persada.

Soerjono, S. (2007). Sosiologi Suatu Pengatar. Jakarta: Raja Grafindo.

Sunyoto. (2012). Dasar-dasar Manajemen. Yogyakarta: CAPS.

Sutarto. (2009). Dasar-dasar Kepemimpinan Administrasi. Yogyakarta: Gajah Mada University Press. 
Totok, M. P. (2015). Pemberdayaan Masyarakat. Bandung: Alfabeta.

Veithzal, R. (2012). Manajemen Sumber Daya Manusia untuk Perusahaan. Jakarta: Raja Grafindo. 